\title{
Growth and survival rates of carpet shell clam (Tapes decussatus Linnaeus, 1758) using various culture methods in Sufa (Homa) Lagoon, Izmir, Turkey
}

\author{
Serpil SERDAR1*, Aynur LÖK1, Aysun KÖSE1, Harun YILDIZ2, Sefa ACARLI 1, \\ Philippe GOULLETQUER3
}

1 Ege University, Fisheries Faculty, 35100, Izmir, Turkey

2 Canakkale Onsekiz Mart University, Fisheries Faculty 17100-Canakkale, Turkey

3 Ifremer-Genetics, Aquaculture, Pathology Research Laboratory, La Tremblade, 17390, France

*: Corresponding author :

Tel.:+90 232343 4000/5216;

fax: +902323883685

E-mail address : serpil.serdar@ege.edu.tr

\begin{abstract}
:
The carpet shell clam (Tapes decussatus Linnaeus, 1758) is a candidate species for aquaculture development in Turkish waters. Our study aimed to assess the efficiency of three different methods (i.e., net, box and fenced ground) to maximize clam production. Two different net materials (hard plastic net and polyamide net) were tested in the net method trials. Conducted over 1 year between October 2001 and October 2002, an initial calibrated clam population, characterized by a $26.25 \pm 0.035 \mathrm{~mm}$ shell length and $3.85 \pm 0.06 \mathrm{~g}$ total wet weight was sampled on a monthly basis to carry out the experiments. By the end of the rearing cycle, clams reached $34.13 \pm 0.38 \mathrm{~mm}$ and $9.09 \pm 0.27 \mathrm{~g}$ in shell length and total wet weight, respectively. Significant differences in shell length and total wet weight among culture methods $(P<0.05)$ were reported. Both maximum growth and total wet weight, as well as survival rate $(64 \%)$ were obtained using the hard plastic net method. Those overall results were likely due to both limited algae accumulation and crab predation when using hard plastic net. Therefore, this method appears the most suitable to develop further larger experimental clam aquaculture trials. Additional studies required to develop clam culture in Turkish waters are discussed.
\end{abstract}

Keywords: Tapes decussatus; Clam; Sufa Lagoon; Culture method; Growth; Survival rate 


\section{Introduction}

The carpet shell clam (Tapes decussatus L.), a commercially valuable bivalve mollusk is naturally found from the south and west coast of the British Isles to the Mediterranean sea and along the Atlantic coast from Norway to Senegal (Tebble 1966; Breber 1985). Tapes decussatus lives in muddy-sand sediments of tidal flats or shallow coastal areas (Parache 1982).

In Turkey, this species is distributed along the coastline of Aegean, Mediterranean and Marmara Seas. This species is a leading candidate for aquaculture in Turkish waters, similarly to other Mediterranean lagoons (Chessa et al., 2005). Actually, a clam population dynamic model has been developed to compare fishery strategies and aquaculture strategies in Venice lagoons (Adriatic Sea), indicating that aquaculture might be more profitable than regulated fishing (Solidoro et al., 2003). T. decussatus has been found abundantly in Aegean Sea, especially in Izmir Bay where the main fishery grounds are located. According to fisheries statistic data (SIS, 2003), overall clam production has reached 19,700 tons (T. decussatus and Venus gallina) per year in Turkish waters. The clam production has been based on fishery from wild stocks.

Clams, like most filter feeders living in the intertidal zone, take advantage of the tidal movement in estuaries: the water currents generated by the tides continuously supply a much larger quantity of food than the amount produced locally and those sites are of critical interest for primary production (Gutiérrez 1991). Mid-estuarine areas usually consist of sand or sandy silt, often suitable for clam cultivation. Although outer estuarine areas may be suitable for clam cultivation, the exposure to wave action is of major concern (Britton 1991). 
Besides physical environmental conditions, clam production is likely to be effected by a wide variety of predators, whose activity and relative importance vary depending on location and season (Anderson et al., 1982). Moreover, small bivalves such as mussels, oysters and clams are preferred foods of shore crabs, one of the most common predators with in estuaries and coastal waters. Clam protection is therefore a critical aspect for shellfish farming development due to the large crab abundance in Turkish waters.

The main interest to develop clam culture within intertidal areas is due to the facilitated access, monitoring and maintenance of protection devices and therefore the resulting reduced costs (Kraeuter and Castagna 1989).

In European waters, clam culture was in itially developed using two main kinds of zootechnical practices, fenced ground and net systems, the latter being particularly well adapted to areas where the substrate has a high silt content (De Valence and Peyre 1990; Britton 1991; Goulletquer 1997). More recently, a third one using box has been developed. Each one is adapted to particular environmental conditions (De Valence and Peyre 1990; Christophersen 1994). Lately, clam culture in oyster bags was considered as a no-alternative to ground culture (Cigarria and Fernandez 2000). Mechanical harvesting process was specifically adapted for each of those techniques. The fenced ground system is based upon the deployment of a fence around the seeded area to be protected from crab predation. Moreover, an aerial net may protect clams from bird predation such as crows and ducks (Bourne 1983; Richardson and Verbeek 1986). The net system consists of strips of mesh laid over the seeded clams and ploughed in along its edges, so making it protected from direct crab predation (Britton 1991). The box is made up of a framework of iron rods, inserted inside a bag made from plastic netting, which has a mesh size corresponding to the size of the smallest seed clam (De Valence 
and Peyre 1990). Therefore three methods can be presently recommended as growout facilities for clam production.

This paper aims to evaluate the three different rearing systems for juvenile carpet shell clam, Tapes decussatus in Sufa Lagoon in Izmir, Turkey. Those rearing systems are fenced ground, net and box methods. Comparisons among methods will facilitate decision making over which cultural practice is the most suitable for clam culture in Sufa Lagoon. Meanwhile, growth and survival rates among those methods will be used to assess the overall culture yield.

\section{Materials and methods}

Study area

This study was conducted in the Sufa lagoon area, located at the outer part of Izmir Bay (northwest of Izmir, 38 $31^{\prime} 10^{\prime \prime}$ north latitude and $26^{\circ} 49^{\prime} 50^{\prime \prime}$ east longitude). This is an important region for commercial fisheries including bivalve (clam, mussel and oyster) located $35 \mathrm{~km}$ away from Izmir city in Aegean Sea (Fig. 1). The various trials of clam culture were carried out inside the lagoon area (1800 ha acreage), at the near vicinity of the main lagoon entrance.

\section{Environmental parameters}

Environmental parameters were measured on a monthly basis over the experimental time. Seawater temperature was determined using a mercury-in-glass thermometer (-10 to $\left.100 \pm 0.5^{\circ} \mathrm{C}\right)$, and the salinity (p.s.u.) with a hand refractometer $( \pm 1$ p.s.u.) at the study area. Meanwhile, seawater samples were analyzed to assess $\mathrm{NO}_{2}^{-}{ }^{-} \mathrm{N}, \mathrm{NO}_{3}{ }^{-}$ $-\mathrm{N}, \mathrm{PO}_{4}{ }^{-3}-\mathrm{P}, \mathrm{NH}_{4}{ }^{+}-\mathrm{N}$ and $\mathrm{SiO}_{4}{ }^{-}-\mathrm{Si}$ nutrient concentrations according to Strickland and 
Parsons (1972) spectrophotometric methods. Dissolved oxygen (DO) levels were estimated according to the chemical Winkler method and $\mathrm{pH}$ levels using a Hanna Model HI 8314 pH meter.

Phytoplankton biomass was estimated by chlorophyll-a measurements according to the spectrophotometric method (Strickland and Parsons 1972). Similarly, the seston amount (TPM- Total Particulate Material) was determined by Strickland and Parsons (1972) method.

\section{Culture methods}

Three different methods were tested as clam growout facilities: box, fenced ground and net (poly amide and hard plastic) (De Valence and Peyre 1990) (Fig. 2).

Selected clam culture areas showed several predators, including crabs and birds, therefore requiring specific protections. To address the issue, the fenced ground was deployed using plastic stakes and a $12 \mathrm{~mm}$ mesh net buried in to the bottom substrate and attached to the stakes. For the net method, two different net materials were tested: hard plastic net and polyamide net (12 mm mesh size). Net was first deployed to design a 'bag' and clams were sown inside and then slightly buried in to the bottom. Each corner of the net was attached to the stakes. Commercial plastic boxes were used in box method. Upper side of the box was covered with $12 \mathrm{~mm}$ mesh net to protect clam seed from predators. Each experimental method was tested using a $0.5 \mathrm{~m}^{2}$ surface and carried out in trip licate. Clam density was chosen to $200 \mathrm{ind} . / \mathrm{m}^{2}$ for all cultural trials .

A calibrated clam population sample was collected from the wild population for growth and survival monitoring. Surveys were conducted from October 2001 to October 2002. Shell length, width, height and total wet weight were measured individually on 
the whole clam population on a monthly basis. Mortality rate was estimated concomitantly by removing open bivalve shells and by checking shell break-up for those resulting from predation. Clam length (along the anterior-posterior axis), width and height were measured using a calliper $( \pm 0.1 \mathrm{~mm})$. Initial average shell len gth and total wet weight were $26.5 \pm 0.5 \mathrm{~mm}$ and $3.88 \pm 0.05$, respectively.

Data analysis

Differences in mean shell length and wet weight among culture methods were determined using a one-way ANOVA, followed by Duncan tests for mean comparison, using statistical program for Social Science (SPSS) 11.0 software. Survival rate data were Arcsin-transformed prior to statistical analys is. Non parametric $\chi^{2}$ (Chi square) tests were applied on survival rate data. Significance levels for all analysis were set at $\mathrm{P}<0.05$.

The instantaneous growth rate $(\mathrm{K})$, was calculated using the following equation (Malouf and Bricelj, 1989):

$$
\mathrm{K}=\left(\ln \mathrm{W}_{2}-\ln \mathrm{W}_{1}\right) /\left(\mathrm{t}_{2}-\mathrm{t}_{1}\right) \quad \mathrm{K}=\left(\ln \mathrm{L}_{2}-\ln \mathrm{L}_{1}\right) /\left(\mathrm{t}_{2}-\mathrm{t}_{1}\right)
$$

$\mathrm{W}_{1}, \mathrm{~W}_{2}$ are the total wet weight. $\mathrm{L}_{1}, \mathrm{~L}_{2}$ are the shell length at the beginning and end of experiment time (in month), respectively. The duration of experiment (months) is expressed by $t,\left(t_{2}-t_{1}\right)$.

Survival (\%) was estimated as $\left(\mathrm{N}_{\mathrm{t}} / \mathrm{N}_{0}\right) \times 100$, where $\mathrm{N}_{\mathrm{t}}$ is the number of live clams removed from the culture area after $\mathrm{t}$ and $\mathrm{N}_{0}$ is the number of clams at the beginning of the experiment.

Annual and monthly mortality ratio were calculated from $\mathrm{Z}=\left(\mathrm{N}_{\mathrm{t}}-\mathrm{N}_{0}\right) / \mathrm{N}_{0}$ where $\mathrm{N}_{0}=$ initial number of individuals, and $\mathrm{N}_{\mathrm{t}}=$ final number of individuals 


\section{Results}

\section{Environmental parameters}

The main environmental parameters in Sufa lagoon over the experimental time are presented on Fig. 3 describing dissolved oxygen, $\mathrm{pH}$, temperature, salinity, $\mathrm{NO}_{2}^{-}-\mathrm{N}$, $\mathrm{NO}_{3}{ }^{-}-\mathrm{N}, \mathrm{PO}_{4}^{-3}-\mathrm{P}, \mathrm{NH}_{4}{ }^{+}-\mathrm{N}, \mathrm{SiO}_{4}{ }^{-}-\mathrm{Si}$ range. From October 2001 to October 2002, temperature ranged between $8^{\circ} \mathrm{C}$ and $32^{\circ} \mathrm{C}$, the highest temperature being recorded in August. Meanwhile, salinity values were recorded between 38 - 43 p.s.u. Highest salinity values were reported in summer months. Dissolved oxygen and $\mathrm{pH}$ values ranged from 8.8 to $11.2 \mathrm{mg} \mathrm{l}^{-1}$ and from 6.87 to 7.43 , respectively.

Chlorophyll- $a$ and seston values are reported on Fig. 4. Chlorophyll-a concentration showed an irregular pattern with minimum and maximum value reaching $4.04 \mu \mathrm{g} \mathrm{l}^{-1}$ and $30.93 \mu \mathrm{g} \mathrm{l}^{-1}$ in April and August, respectively. In January, seston level showed a $23 \mathrm{mg}^{-1}$ record low while the maximum $184 \mathrm{mg}^{-1}$ was recorded in February.

\section{Growth}

Shell growth and total wet weight steadily increased over the year. Maximum growth was obtained in hard plastic net of the 'net' method. By the end of the study, shell length, width and height and total wet weight were $34.13 \pm 0.38 \mathrm{~mm}, 26 \pm 0.35 \mathrm{~mm}$, $14.11 \pm 0.23 \mathrm{~mm}$ and $9.09 \pm 0.27 \mathrm{~g}$, respectively (Figure $5 \mathrm{~A}, \mathrm{~B}, \mathrm{C}, \mathrm{D}$ ). Minimum growth was obtained in the 'fenced ground' method with $31.93 \pm 0.49 \mathrm{~mm}$ and $6.72 \pm 0.19 \mathrm{~g}$, for the shell length and total wet weight, respectively. Using the 'box' and 'polyamide net' methods, clams reached $32.56 \mathrm{~mm}, 8.02 \mathrm{~g}$ and $32.25 \mathrm{~mm}, 7.24 \mathrm{~g}$, respectively (Fig. $5 \mathrm{~A}$

- D). Significant differences were reported in shell length and total wet weight values among different culture methods (ANOVA $\mathrm{P}<0.05)$. 
The maximum shell growth and to tal wet weight rates were significantly higher in spring months compared to other periods of time. Shell growth rate in hard plastic net was $0.032,0.029$ and 0.030 in March, April and May, respectively. Meanwhile, growth rate of total wet weight in hard plastic net was $0.13,0.088$ and 0.085 during this period. Growth rate of total wet weight in polyamide net and box were a record high in March (0.1231 and 0.0782), except in fenced ground where maximum value of total wet weight was reported in April (0.0766). For all methods, both hard plastic net, polyamide net, box and fenced grounds, minimal growth rates were observed in September $(0.0346,0.0329,0.0237$ and 0.0286 , respectively). Maximum growth rate of shell length in fenced ground, box and polyamide net were observed concomitantly to seawater temperature increase with 0.0254 (March), 0.0259 (April) and 0.0253 (July), respectively. Minimum growth rate of shell length in hard plastic net was 0.0052 in October 2001 while reaching $0.0014,0.0044$ and 0.0037 in November for polyamide net, box and fenced grounds, respectively (Fig. 6).

\section{Survival rate}

Survival rates in hard plastic net, polyamide net, box and fenced grounds were $64 \%, 32 \%, 42 \%$ and $42 \%$, respectively by the end of the study. Although survival rate was higher in hard plastic net compared to other culture methods (box and fenced ground), these differences were not found significant at the statistical analysis $(\mathrm{P}>0.05)$. In contrast, sign if icant difference was observed between hard plas tic net and polyamide net $(\mathrm{P}<0.05)($ Fig 7$)$.

Mortality rates showed the highest values in December 2001 and August 2002. Significant differences among rearing systems were observed in December 2001 with $14.28 \%, 30.61 \%, 18.36 \%$ and $20.40 \%$ for hard plastic net, polyamide net, box and 
fenced ground, respectively. By the end of the experiment, total mortality rates were $11.11 \%, 23.80 \%, 18.18 \%$ and $19.23 \%$ for hard plastic net, polyamide net, box and fenced ground, respectively.

\section{Discussion}

Clam growth is affected by temperature, salinity, exposure regimes as well as food availability (Laing et al., 1987; Bacher and Goulletquer 1988; Goulletquer and Bacher 1988; Daou and Goulletquer 1988; Goulletquer et al., 1989, 1999; Chew 1989; Baud and Bacher 1990; Chool-Shin and Shin 1999; Sobral and Widdows 2000). Lucas (1978) reported that growth is still on-going in winter conditions $\left(8^{\circ} \mathrm{C}\right)$, assuming food availability while pumping activity decreases drastically below a $6-7^{\circ} \mathrm{C}$ threshold. Those seawater conditions were reached in our study in November 2001 with an $8^{\circ} \mathrm{C}$ record low. However, Walne (1976) pointed out that growth ceased when the temperature was declining to about $10^{\circ} \mathrm{C}$ (mid-October). In this case, the growth season was lasting from March/April to October/November (or $9^{\circ} \mathrm{C}$ ) with a significant food level in seawater in Donegal Bay (Britton 1991). In our environmental conditions, seawater temperature was $11-13.5^{\circ} \mathrm{C}$ during the winter mon ths (December, January and February). In summer, seawater temperature (June, July and August) reached 27.5$32^{\circ} \mathrm{C}$. Although our summer temperature peak reached a record value, our data were globally consistent with those resulting from a literature review in the same area (Table 2). Chlorophyll-a concentration fluctuated (4.04-30.93 $\mu \mathrm{g}^{-1}$ ) throughout the study while seston values were also highly variable. This variability is likely resulting from seaw ater exchan ges between open-sea and lagoon.

With regard to clam growth, a number of studies showed that variations in length and dry meat weight were characterized by a seasonal pattern with marked increases 
during spring and summer and slight decreases of these parameters during the winter (Bacher and Goulletquer 1988; Soudant et al., 2004). According to Claus (1981), Baud and Bacher (1990), a positive relationship is occurring between growth and temperature. Goulletquer et al., $(1988,1989)$ reported that maximum growth rates were observed at the higher temperatures for the culture of $R$. philippinarum using an ecophysiological model approach. Melia et al. (2004) described the dependence of growth and mortality rates upon seasonal temperatures using a stochastic model. They concluded on the importance of temperature as a key variable in vital processes and underlined the alternation of favourable and unfavourable periods for seeding and harvesting. In this study, a maximum growth rate was observed in spring season, when seawater temperature reached $22-25.7^{\circ} \mathrm{C}$ (April-May) whatever the cultural method. Shpigel and Fridman (1990) pointed out that the highest growth rates were observed in Eilat throughout the year $\left(19-27^{\circ} \mathrm{C}\right.$ range $)$ with the exception of spawning period in summer. Baud and Bacher (1990) indicated that high temperatures enhanced the bivalve metabolism but usually coincided with a reduction in food availability due to the limited phytoplankton in the natural environment. Moreover, they indicated that at low temperature the bivalve metabolism decreases and hence their assimilation capacity, while low temperatures combined with poor daylight lead to a near lack of phytoplanktonic food.

Although salinity and oxygen values can affect the grow th of $R$. decussatus, JaraJara et al. (1997) reported that salinity (22-34 p.s.u.) and oxygen values (5.9-7 $\mathrm{mg} \mathrm{l}^{-1}$ ) did not appear to have a noticeable affect, since they were stable and suitable for the clam growth. In Sufa Lagoon, salinity values varied from 38 to 43 p.s.u. throughout the study, especially in summer time when salin ity value peaked at $40.5-43$ p.s.u. Therefore, this parameter may have affected the overall clam growth. 
In Sufa Lagoon area, shell length and total wet weight increments of $T$. decussatus were $7.44 \mathrm{~mm} \mathrm{year}^{-1}$ and $5.24 \mathrm{~g} \mathrm{year}^{-1}$ in hard plastic net, respectively. Growth in hard plastic net was faster compared to other methods $(5.77 \mathrm{~mm}$ and $4.15 \mathrm{~g}$ in box; $5.44 \mathrm{~mm}$ and $3.31 \mathrm{~g}$ in polyamide net; $5.05 \mathrm{~mm}$ and $2.90 \mathrm{~g}$ in fenced ground). Therefore, the overall growth performance during this study was lower than those recorded by Shpigel and Fridman (1990), Breber (1985) but greater than Yamamoto and Iwata (1956) results (34.4 $\mathrm{mm}$ in 3 years). Differences in mollusc growth have often been associated with differences in food availability. However, species differences exist since Manila clam $R$. philippinarum growth is considered as faster than the European endemic $T$. decussatus growth, over a wide temperature range, explaining its choice as a cultured species in European waters (Laing et al., 1987). A review of clam performance is provided in Table 1.

In this study, our site observations showed that when seawater temperature increased, especially summer months, accumulation of macroalgae (Ulva lactuca) was high on cultural facilities and cultured areas. However, algal accumulation in hard plastic net was lower compared to the other cultural methods. Since seawater exchange was also improved in hard plastic net compared to the others, overall growth rate was significantly higher due to increased food availability. Extensive algal blooms of the seaweed Ulva rigida is considered in Italy as the major cause of the decline of $R$. philippinarum production (Melia et al., 2004). Breber (1985) indicated that the potential clam culture in Venice Lagoon was limited by the macroalgae, U. rigida and Gracilaria sp., which expansion is significant in summer months, prompting the shellfish farmers to rake off their structures at least once a week.

Several investigations showed that the Manila clam survives and grows better than the carpet shell clam (De Valence and Peyre 1990). Growth to market size takes one 
more then one year for T. decussatus (6-10 $\left.\mathrm{mm} \mathrm{year}^{-1}\right)$ compared to Manila clam (10-15 $\mathrm{mm}^{-1}$ ) in the UK and Ireland (Lake 1992). Manila clams reach commercial size in 18 to 24 months, with a 60-80\% overall survival rate (Gutiérrez 1991) and 3-4 years in Donegal Bay (Irleand) (Britton 1991).

The other critical factor over a rearing cycle is mortality rate, which can be either affected by hydrological parameters (Gribben et al., 2002), substratum type (Cigarria and Fernández 1998), culture method (Breber 1985), planting season (Anderson et al., 1982), seed size (Spencer et al., 1991), predation (Toba et al., 1992) and pathogens (Breber 1985).

According to our field observations, predation by crab Carcinus aestuarii (Nordo 1847) was one issue in our study area. Plastic net, a hard structure, is usually considered as a more suitable against crab predation (De Valence and Peyre 1990). In contrast, crab predation was a maximum when using the polyamide net, a soft structure.

Spencer et al. (1991) reported that the usual way of excluding crabs was to cover the clam beds with plastic netting. This can easily retain the clams whereas the concomitant suitable seawater exchange, and therefore food availability to ensure appropriate growing conditions. The net must be sufficiently hard to prevent crab predation by crushing and eating the clams throughout net apertures. Although, protection from predators is considered higher in the box method, crab larvae may have the capacity to develop inside the structure (De Valence and Peyre 1990). In our study, mortalities may result either from the effects of algal accumulation or/and crab predation.

Site selection remains a critical factor for clam production since clam spat is sown into substrate for on-growing (Arnold et al., 2000). In addition to biotic and abiotic factors such as substrate characteristics, seawater current, food availability, local fauna 
and flora, socio-economic parameters should also be considered (e.g., spatial conflicts among users) before setting up a clam farm (Britton 1991; Christophersen 1994; Pellizzato and Da Ros 2005). A suitability index should be established to balance pros and cons to facilitate decision-making. By way of example, installation cost is rather low using the net method whereas algae accumulation is also lower in net method, although all methods need regular cleaning (De Valence and Peyre 1990). In this study, algae accumulation in hard plastic net was lower than in other methods. However, attachment of cuttle fish eggs was observed between April and June at the edge of culture box in the lagoon area. Cuttle fish eggs covered all sides of box and prevented seawater exchange. Meanwhile, those exchanges were limited when using the fenced ground and box methods due to the fouling effect. Costs associated to harvesting should also be considered: using box method and net methods lead to reduced costs compared to fenced ground (De Valence and Peyre 1990).

Moreover, a GIS based habitat suitability model could be developed at a larger scale by using the aforementioned parameters as well as additional ones such as water depth. This type of approach has been developed on a Mediterranean lagoon (Sacca di Goro Lagoon, Adriatic Sea) leading to a GIS mapping process for site selection to develop Manila clam culture (Vincenzi et al., 2006). Another potential approach would focus on a decision support system based upon carrying capacity model using both spatial criterion and primary production. This represents a further development likely being useful to estimate how a new rearing activity may affect the environment and analyse the relationship between the yield and seeding density, therefore overall economic yield (Pastres et al., 2001).

As a preliminary conclusion, growth and survival rate in hard plastic net showed that improved results for clam production in Sufa Lagoon compared to polyamide net, 
box and fenced ground. Those overall results are likely due to limited algae accumulation and crab predation when using hard plastic net, and therefore this method appears to be the most suitable to be adapted to larger experimental clam aquaculture trials. The next step to develop further guidelines for an efficient and sustainable clam culture will focus in assessing the most favourable periods for seeding according to environmental conditions and economic cost-efficiency. This could be addressed by developing population dynamic models which could provide suggestions for an optimal seeding size and seeding moment similarly to those from Solidoro et al. (2003), and by a stochastic bioeconomic model to provide guidelines for optimal management. (Melia and Gatto, 2005).

\section{References}

Anderson, G. J., Miller, M. B., Chew, K. K., 1982. A guide to Manila clam aquacu lture in Puget Sound. Washington Univ. Wash. Sea Grant Prog. Publ.No. WSG, Seattle, WA, pp. 45.

Arnold, W.S., White, M.W., Norris, H.A., Berrigan, M.E. 2000. Hard clam (Mercenaria spp.) aquaculture in Florida, USA: geographic information system applications to lease site selection. Aquacultural En gineer ing 23, 203-231.

Bacher, C., Goulletquer, P. 1988. Comparaison des relations trophiques de Ruditapes philippinarum en milieu estuarien et océanique à partir d'un modèle de croissance. Jour. Canad. des Sci. Halieut. et Aquat., 46, 1160-1170.

Baud, J. P., Bacher, C., 1990. Use of saline ground water for intensive rearing of Ruditapes philippinarum juveniles in a nursery system. Aquaculture 88, 157178. 
Bourne, N., 1983. Clam predation by scoter ducks in the Strait of Georgia, British Columbia. J. Shellfish Res. 3, 84.

Breber, P., 1985. On-growing of the carpet shell clam (Tapes decussatus (L.): Two years' experience in Venice Lagoon. Aquaculture 44, 51-56.

Britton, W., 1991. Clam cultivation manual. Aquaculture explained No.8. Shellf ish file. Aquaculture Technical Section, An Bord Iascigh Mhara, Ireland. A special publication in conjuction with Taighde Mara Teo. pp. 60.

Chessa, L. A., Paesanti, F., Pais, A., Scardi, M., Serra, S., Vitale, L., 2005. Perspectives for development of low impact aquaculture in a western Mediterranean lagoon: the case of the carpet clam Tapes decussatus. Aquaculture International 13, 147-155.

Chew, K. K., 1989. Manila clam biology and fishery development in Western North America. In: Manzi J J, Castagna M, (eds) Clam mariculture in North America. Elsevier, Amsterdam. pp. 243-262.

Chool-Shin, H., Shin, S. H., 1999. Population biology of short necked clam Ruditapes philippinarum: Bivalvia) in Kwangyang Bay, Southern coast of Korea. I. Growth and benthic environments. Korean Journal of Malacology 15, 21-30

Christophersen, G., 1994. Aquaculture production of the carpet shell Tapes decussatus. SMR-report 12/94. Universitetet I Bergen Senter For Miljo-Og Ressursstudier.

Cigarria, J., Fernández, J. M. 1998. Management of Manila clam beds. I. Influence of seed size, type of substratum and protection on initial mortality. Aquaculture $182,173-182$.

Cigarria, J., Fernández, J. M., 2000. Manila clam Ruditapes philippinarum culture in oyster bags: influence of density on survival, growth and biometric relationships. J. Mar. Biol. Ass. UK, 78, 551-560. 
Claus, C., 1981. Trends in nursery rearing of bivalve molluscs. In: C.Claus, N.de Pauw and E.Jaspers (Editors), Nursery Culturing of Bivalve Molluscs. EMS Spec. Publ. No. 7. European Mariculture Society, Bredene, Belgium, pp.1-33.

Daou, R., Goulletquer, P., 1988. Effets de la turbidité sur les palourdes adultes Ruditapes philippinarum (Adams \& Reeve): croissance, effort de reproduction, composition biochimique, mortalité. Oceanis 14, 375-389.

De Valence, P., Peyre, R., 1990. Clam culture. In: Barnabé G, (ed) Aquaculture, 2nd ed. Ellis Horwood, Chichester, UK Vol.1., pp. 388-415.

Goulletquer, P., Bacher, C., 1988. Empirical modelling of the growth of Ruditapes philippinarum by means of non-linear regression on factorial coordinates. Aquatic Living Resources 1, 141-154.

Goulletquer, P., Nedhif, M., Héral, M., 1988. Production de la palourde japonaise Ruditapes philippinarum en bassins semi-fermés (claires): approche énergétique et relations trophiques. Aquaculture 74, 331-348.

Goulletquer, P., Deslous-Paoli, J.M., Héral, M., 1989. Ecophysiologie et Bilan Energétique de la palourde japonaise d'élevage Ruditapes philippinarum. Jour. Exp. Mar. Biol. Ecol. 132, 85-108.

Goulletquer, P., 1997. A bibliography of the Manila clam Tapes philippinarum. RI DRV RA 97.02 La Tremblade, pp. 122.

Goulletquer, P., Robert, R., Trut, G., 1999. Manila clam Tapes philippinarum culture: Sediment-clam interactions. Aquat. Living Res. 12, 45-56.

Gribben, PE., Creese, R. G., Hooker, S. H., 2002. Growth rates of the venus clam Ruditapes largillierti grown under experimental culture conditions in New Zealand. Aquaculture 213, 187-197.

Gutiérrez E, 1991 Clam culture in Europe. Aquaculture Europe 15, 8-15. 
Jara-Jara, R., Pazos, A. J., Abad, M., Garcia-Martin, L. O., Sànchez, J. L., 1997. Growth of clam seed (Ruditapes decussatus) reared in the wastewater effluent from a fish farm in Galicia (N.W. Spain). Aquaculture 158, 247-262.

Korkut, A.Y., Cihaner, A., Tolon, M.T., 1997. Effects of physico-chemical variations on fish yield in Sufa Lagoon. In: B. Hossu (Ed.) Mediterranean Fisheries Congress, Izmir, pp:615-620.

Kraeuter, J. N., Castagna, M., 1989. Factors affecting the growth and survival of clam seed planted in the natural environment. In: Manzi J. J., Castagna M., (eds) Clam mariculture in North America. Els evier, Amsterdam. pp. 149-165.

Laing. I., Utting, S. D., Kilada, R. W., 1987. Interactive effects of diet and temperature on the growth of juvenile clams. J. Exp. Mar. Biol. Ecol. 113, 23-38.

Lake, N. C. H., 1992. Assessment of the potential for Manila clam (Tapes philippinarum) cultivation on the Scottish west coast. Seafish report no. 400, Sea fish industry authority, Marine farming unit, Ardtoe, Scotland. pp. 33.

Lucas, A., 1978. Croissance de jeunes palourdes (Venerupis semidecussata, Reeve) en nurserie et en mer en fonction des conditions d'élevage. Publ.Sci.Tech., Actes Colloq. CNEXO, 7: 85-104.

Malouf, R. E., Bricelj, V. M., 1989. Comparative biology of clams: environmental tolerances, feeding and growth. In: Manzi J J, Castagna M (eds.) Clam mariculture in North America. Els evier, Amsterdam, pp. 23-73.

Melia, P., M. Gatto, 2005. A stochastic bioeconomic model for the management of clam farming. Ecological Modelling, 184:163-174.

Melia, P., De Leo, G. A., Gatto, M., 2004. Density and temperature dependence of vital rates in the Manila clam Tapes philippinarum: a stochastic demographic model. Marine Ecol. Prog. Ser. 272, 153-164. 
Önen, M., Yaramaz, Ö., 1991. Phsico-chemical parameters and variations of macrobenthic fauna dependence on the seasons and the years in Homa. In: Fisheries Symposium, 12-14 November, pp 413-428, Izmir, Turkey.

Önen, M., Egemen, Ö., 1997. Investigations on macrobenthic organisms and physicochemical parameters of Homa (Süfa) Lagoon. XIII. National Biology Congress. 24-34pp.

Parache, A., 1982. La palourde. La Pêche Maritime. 1254: 496-507.

Pastres R., C. Solidoro, G. Cossarini, D. Melaku Canu, C. Dejak, 2001. Managing the rearing of tapes philippinarum in the lagoon of Venice: a deciszion support system. Ecological Modelling, 138:231-245.

Pellizzato, M., Da Ros, L., 2005. Clam farming quality as a management tool: a proposal based on recent studies in Northern Adriatic lagoons. Aquaculture International 13, 57-66.

Richardson, H., Verdeek, N. A., 1987. Diet selection by yearling Northwestern craws (Corus caurinus) feeding on littleneck clams Venerupis japonica. The Auk, 104, 263-269.

Shpigel, M., Fridman, R., 1990. Propagation of the Manila clam (Tapes semidecussatus), in the effluent of fish aquaculture ponds in Eilat, Israel. Aqu culture 90, 113-122.

SIS, 2003. Fisheries Statistics, State Institute of Statis tics, Ankara, Republic of Turkey. Sobral, P., Widdows, J., 2000. Effects of increasing current velocity, turbidity and particle-size selection on the feeding activity and scope for growth of Ruditapes decussatus from Ria Formosa, southern Portugal. J. exp. Mar. Biol. Ecol. 245, 111- 125 . 
Solidoro C., D. Melaku Canu, R. Rossi, 2003. Ecological and economic considerations on fishing and rearing of Tapes philippinarum in the lagoon of Venice. Ecological Modelling, 170:303-318.

Soudant, P., Paillard, C., Choquet, G., Lambert, C., Reid, H. I., Marhic, A., Donaghy, L., Birkbeck, T. H., 2004. Impact of season and rearing site on the physiological and immunological parameters of the Manila clam Venerupis (=Tapes, Ruditapes) philippinarum. Aquaculture 229,401-418.

Spencer, B. E., Edwards, D. B., Millican, P. F., 1991. Cultivation of Manila clams. Laboratory LeafletMinistry of Agriculture, Fisheries and Food Directorate of Fisheries Research, No.65, pp.29.

Strickland, J. D. H., Parsons T. R., 1972. A practical Handbook of Seawater Analysis. Fish.Res.Brd.Canada, Bull., pp. 310.

Tebble, N., 1966. British bivalve seashells. A handbook for identification. The British Museum pp. 211.

Toba, D. R., Tompson, D. S., Chew, K. K., Anderson, G. J., Miller, M. B., 1992 Gu ide to manila clam culture in Washington. Seattle, WA, USA, Sea Grant Programme, University of Washington. pp. 80.

Ünsal, S., Büyükışık, B., Akyol, O., 2000. Discussion on the results of physicochemical parameters of the Homa Lagoon (Izmir Bay, Aegean Sea). Journal of Fisheries and Aquatic Sciences 17 (1-2): 85-94.

Vincenzi S., G. Caramori, R. Rossi, G.A. De Leo, 2006. A GIS-based habitat suitability model for commercial yield estimation of Tapes philipinarum in a Mediterranean coastal lagoon (Sacco di Goro, Italy). Ecological Modelling, 193: 90-104. 
Walne, P. R., 1976. Experiments on the culture in the sea of the butterfish Venerupis decussata. Aquaculture 8:371-381.

Yamamoto, K., Iwata, F., 1956. Studies on the bivalve, Venerup is japonica, in Akkeshi Lake II. Growth rate and biological minimum size. Bull. Hokkaido Reg. Fish Res. Lab. 14:57-62.

Yaramaz, Ö., Alpbaz, A., 1990. Recherches des paramètres physico-chimiques, des sels nutritifs et des détergents anioniques dans la pêcherie de Homa d'Izmir Thalassographica, Vol. 13/Suppl. 3/67-69. 


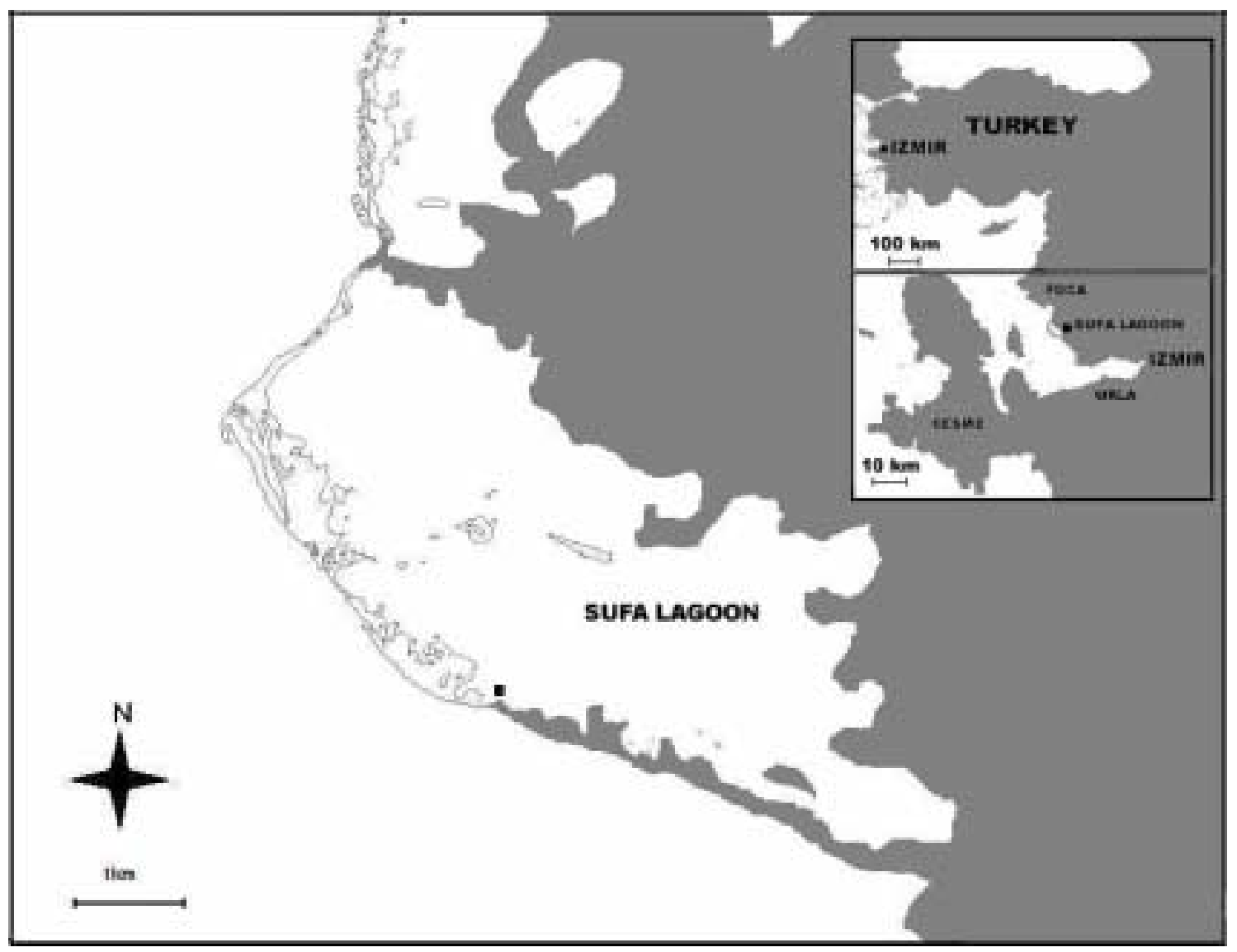

Fig. 1. Location of experimental sites. 


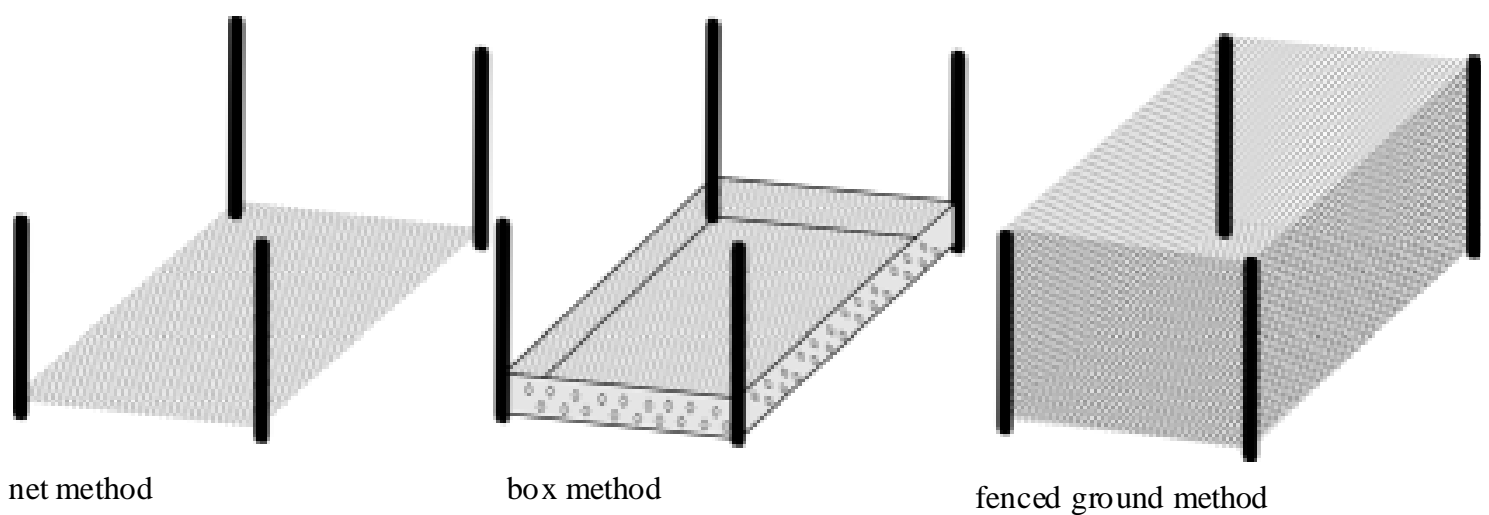

Fig. 2. Description of the three tested methods: net, box and fenced ground method 

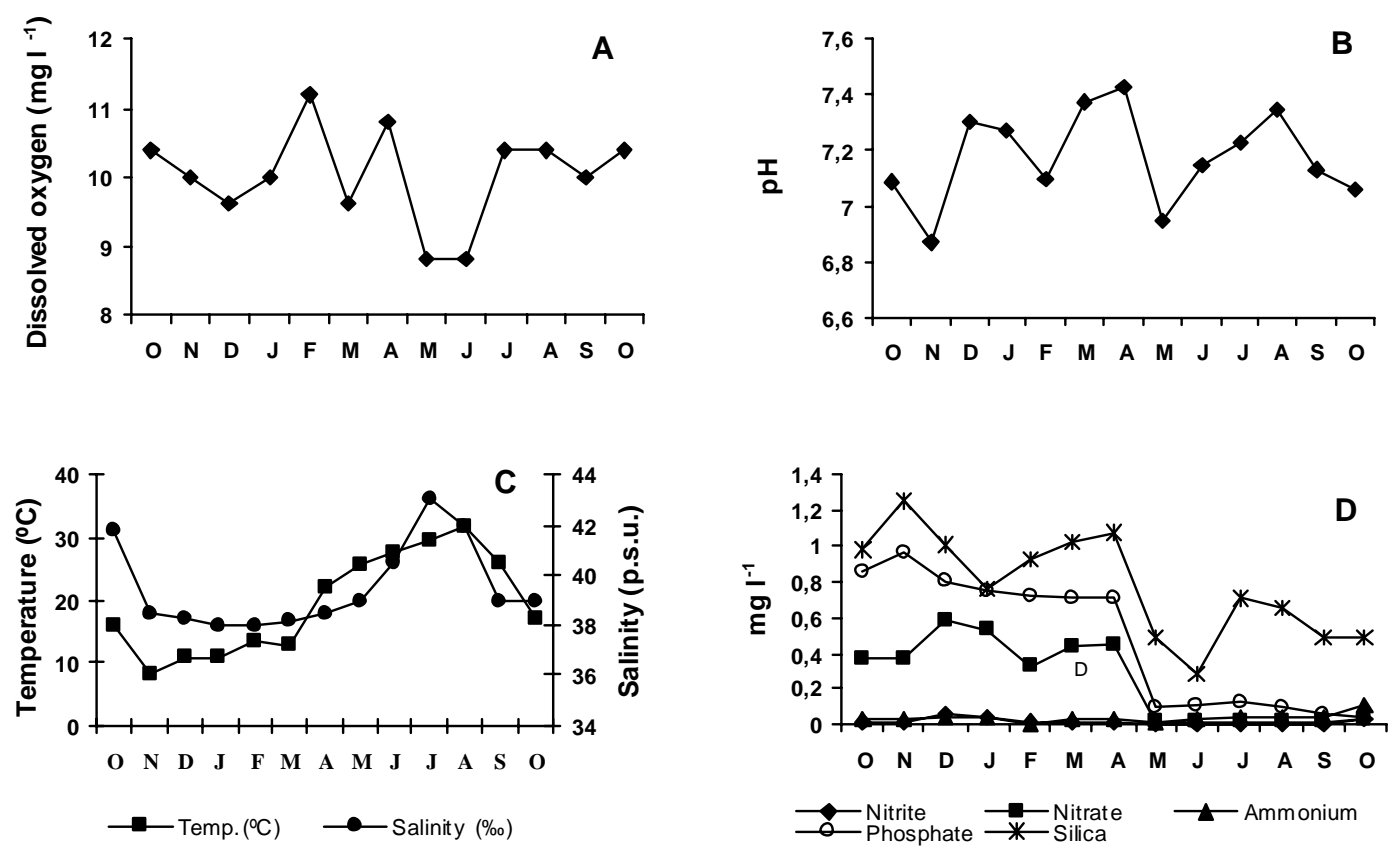

Fig. 3. Monthly variability of hydrological parameters: A: dissolved oxygen, $\mathrm{B}: \mathrm{pH}, \mathrm{C}$ : temperature and salinity, $\mathrm{D}: \mathrm{NO}_{2}{ }^{-}-\mathrm{N}, \mathrm{NO}_{3}{ }^{-}-\mathrm{N}, \mathrm{PO}_{4}{ }^{-3}-\mathrm{P}, \mathrm{NH}_{4}{ }^{+}-\mathrm{N}$ and $\mathrm{SiO}_{4}{ }^{-}-\mathrm{Si}$ 

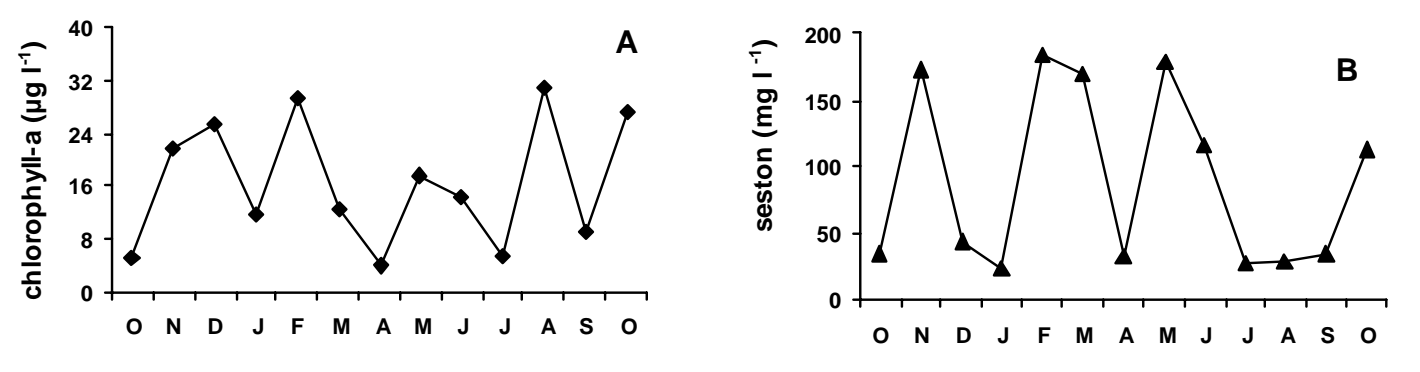

(B)

(A)

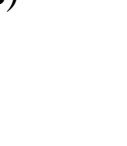

Fig. 4. Monthly variability of Chlorophyll- $a$ (A) and seston (TPM) (B) 

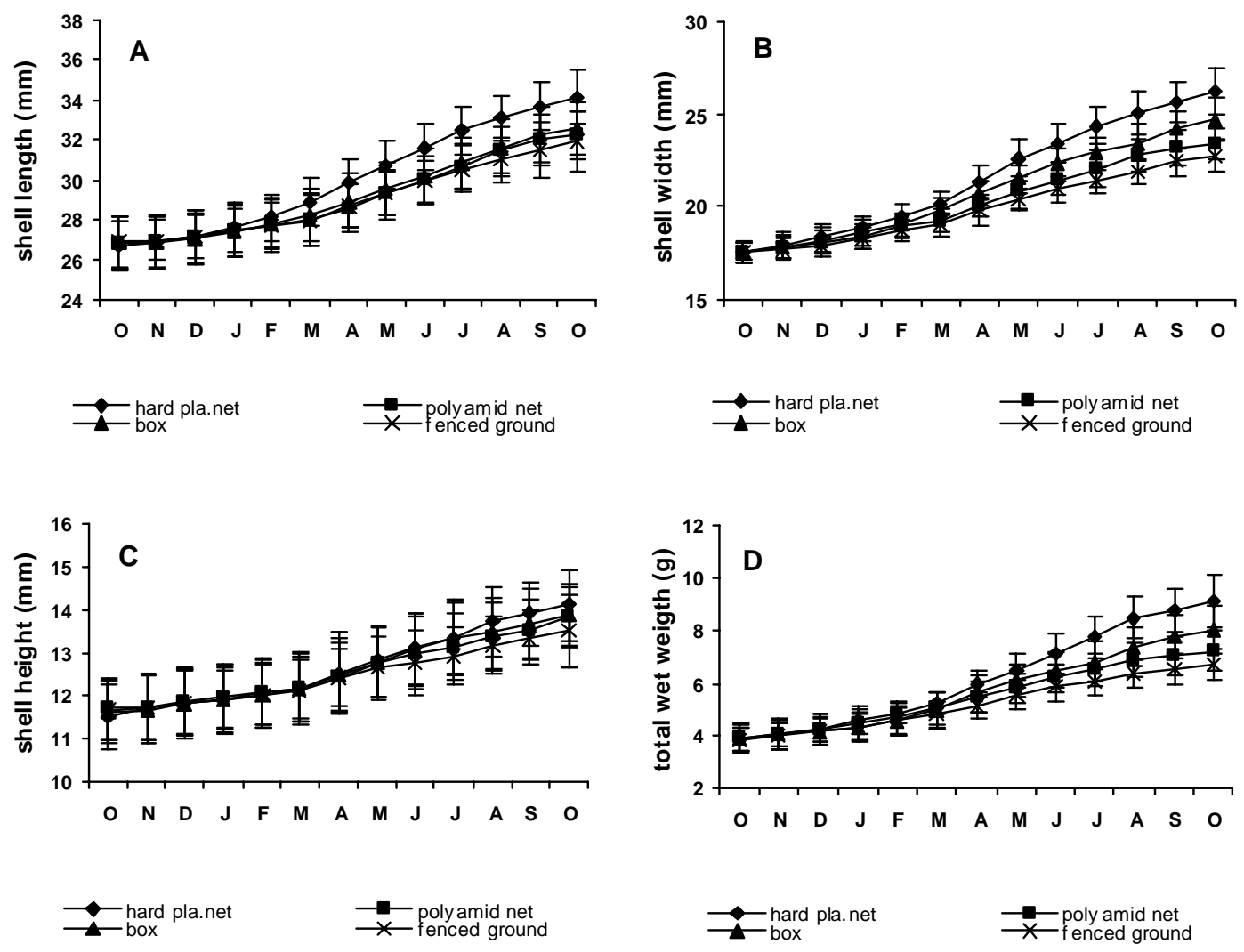

Fig. 5. Effects of different methods on shell length (A), width (B), height (C) and total wet weight (D) $(n=100, \pm$ s.d.) 

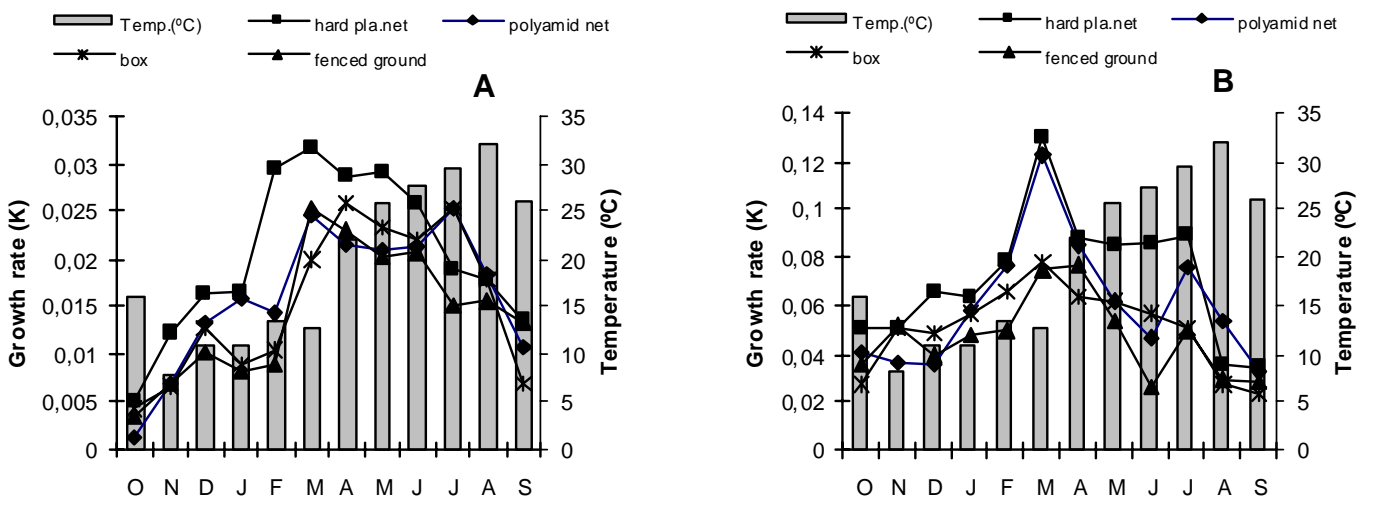

Fig. 6. Growth rate of shell length (A) and total wet weight (B) 


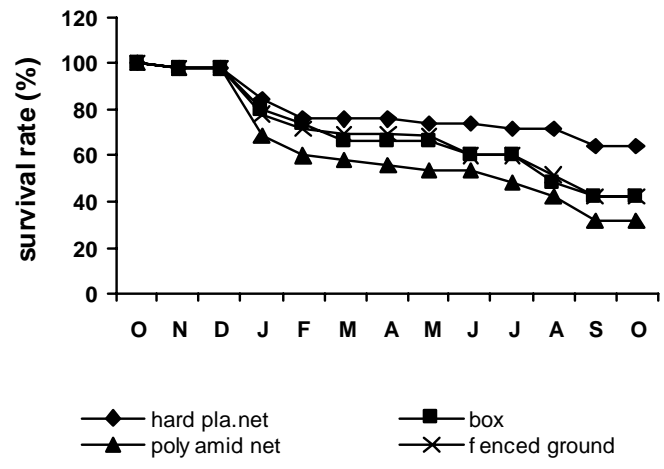

Fig. 7. Survival rates of clams using different culture methods. 
Table 1.

Growth and survival comparison of clam at different sites

\begin{tabular}{|c|c|c|c|c|c|c|c|}
\hline Species & $\begin{array}{l}\text { Initial wet } \\
\text { weight }(\mathrm{g})\end{array}$ & $\begin{array}{l}\text { Final w et } \\
\text { weight }(\mathrm{g})\end{array}$ & $\begin{array}{l}\text { Survival } \\
\text { rate }(\%)\end{array}$ & $\begin{array}{l}\text { Culture } \\
\text { method }\end{array}$ & Time & Site & References \\
\hline T. decussatus & 3.85 & 9.09 & 64 & $\begin{array}{l}\text { Hard P lastic } \\
\text { Net }\end{array}$ & 1 year & $\begin{array}{l}\text { SUFA Lagoon, } \\
\text { İzmir, Turkey }\end{array}$ & Present study \\
\hline T. decussatus & 3.87 & 8.02 & 42 & Box & 1 year & $\begin{array}{l}\text { SUFA Lagoon, } \\
\text { İzmir, Turkey }\end{array}$ & Present study \\
\hline T. decussatus & 3.93 & 7.24 & 32 & $\begin{array}{l}\text { Polyamide } \\
\text { net }\end{array}$ & 1 year & $\begin{array}{l}\text { SUFA Lagoon, } \\
\text { İzmir, Turkey }\end{array}$ & Present study \\
\hline T.decussatus & 3.82 & 6.79 & 42 & $\begin{array}{l}\text { Fenced } \\
\text { ground }\end{array}$ & 1 year & $\begin{array}{l}\text { SUFA Lagoon, } \\
\text { İzmir, Turkey }\end{array}$ & Present study \\
\hline T. decussatus & 2.7 & 9.5 & - & Frame & $\begin{array}{l}10 \\
\text { months }\end{array}$ & $\begin{array}{l}\text { Conwy, Great } \\
\text { Britain }\end{array}$ & Walne, 1976 \\
\hline T. decussatus & 1.4 & 5.5 & 90 & $\begin{array}{l}\text { Fenced } \\
\text { ground }\end{array}$ & 8 months & $\begin{array}{l}\text { Venice Lagoon, } \\
\text { Italy }\end{array}$ & Breber, 1985 \\
\hline T. decussatus & 6.2 & 11.5 & 75 & $\begin{array}{l}\text { Fenced } \\
\text { ground }\end{array}$ & 8 months & $\begin{array}{l}\text { Venice Lagoon, } \\
\text { Italy }\end{array}$ & Breber, 1985 \\
\hline T.decussatus & 0.287 & 0.343 & 40 & $\begin{array}{l}\text { Fenced } \\
\text { ground }\end{array}$ & 120 days & $\begin{array}{l}\text { Ebro's Delta, } \\
\text { Spain }\end{array}$ & $\begin{array}{l}\text { Puigcerver, } \\
1996\end{array}$ \\
\hline T. decussatus & 0.287 & 0.698 & 80 & $\begin{array}{l}\text { Polyculture } \\
\text { pond }\end{array}$ & 120 days & $\begin{array}{l}\text { Ebro's Delta, } \\
\text { Spain }\end{array}$ & $\begin{array}{l}\text { Puigcerver, } \\
1996\end{array}$ \\
\hline R. philippinarum & 1.9 & 18.35 & $88-90$ & Fish pond & $\begin{array}{l}13 \\
\text { months }\end{array}$ & Eilat, Israel & $\begin{array}{l}\text { Shpige } 1 \text { and } \\
\text { Fridman, } \\
1990\end{array}$ \\
\hline R. philippinarum & 0.0078 & 0.8 & - & Frame & 1 year & $\begin{array}{l}\text { Donegal Bay, } \\
\text { Irland }\end{array}$ & Britton, 1991 \\
\hline R. philippinarum & 0.8 & 25 & - & $\begin{array}{l}\text { Fenced } \\
\text { ground }\end{array}$ & 2.5 year & $\begin{array}{l}\text { Donegal Bay, } \\
\text { Irland }\end{array}$ & Britton, 1991 \\
\hline T. dorsatus & 0.64 & 4.1 & 84 & Box & 4 months & $\begin{array}{l}\text { Port Stephans, } \\
\text { AU }\end{array}$ & $\begin{array}{l}\text { Paterson and } \\
\text { Nell, } 1997\end{array}$ \\
\hline T. dorsatus & 0.64 & 2.8 & 81 & Floating box & 4 months & $\begin{array}{l}\text { Port Stephans, } \\
\text { AU }\end{array}$ & $\begin{array}{l}\text { Paterson and } \\
\text { Nell, } 1997\end{array}$ \\
\hline
\end{tabular}


Table 2 : Comparison of environmental conditions in Sufa lagoon between a literature review and the present study.

\begin{tabular}{|c|c|c|c|c|c|c|c|c|c|c|c|}
\hline Author & $\begin{array}{l}\text { Temp. } \\
\left({ }^{\circ} \mathrm{C}\right)\end{array}$ & $\begin{array}{l}\text { Salinity } \\
\text { (p.s.u.) }\end{array}$ & $\begin{array}{c}\text { Dissolved } \\
\text { oxygen } \\
\left(\mathrm{mg} \mathrm{l}^{-1}\right)\end{array}$ & $\mathrm{pH}$ & $\begin{array}{c}\mathrm{NO}_{2}{ }^{-}-\mathrm{N} \\
\left(\mathrm{mg} \mathrm{l}^{-1}\right)\end{array}$ & $\begin{array}{l}\mathrm{NO}_{3-}^{-}-\mathrm{N} \\
\left(\mathrm{mg} \mathrm{l}^{-1}\right)\end{array}$ & $\begin{array}{c}\mathrm{NH}_{4}{ }^{+}-\mathrm{N} \\
\left(\mathrm{mg} \mathrm{l}^{-1}\right)\end{array}$ & $\begin{array}{c}\mathrm{PO}_{4}^{-3}-\mathrm{P} \\
\left(\mathrm{mg} \mathrm{l}^{-1}\right)\end{array}$ & $\begin{array}{c}\mathrm{SiO}_{4}{ }^{=}-\mathrm{Si} \\
\left(\mathrm{mg} \mathrm{l}^{-1}\right)\end{array}$ & $\begin{array}{l}\text { Chl.-a } \\
\left(\mu g l^{-1}\right)\end{array}$ & $\begin{array}{l}\text { Seston } \\
(\mathrm{mg} / \mathrm{l})\end{array}$ \\
\hline $\begin{array}{l}\text { Yaramaz } \\
\text { and Alpbaz } \\
(1990)\end{array}$ & $4.0-26.0$ & $33.9-38.6$ & $7.2-10.0$ & $7.5-7.8$ & $0.1-1.1$ & $0.5-5.1$ & $2.6-21.5$ & $0.2-3.1$ & $1.6-14.3$ & - & - \\
\hline $\begin{array}{l}\text { Önen and } \\
\text { Yaramaz } \\
\text { (1991) }\end{array}$ & $5.0-26.0$ & $34.5-72.1$ & $4.8-11.6$ & $6.9-8.4$ & - & - & - & - & - & - & - \\
\hline $\begin{array}{l}\text { Korkutet } \\
\text { al. (1997) }\end{array}$ & $7.1-27.1$ & $39.2-72.3$ & $6.4-8.8$ & - & - & - & - & - & - & - & - \\
\hline $\begin{array}{l}\text { Önen and } \\
\text { Egemen } \\
(1997)\end{array}$ & $10.2-28.0$ & $40.3-70.2$ & $4.0-8.0$ & $7.8-8.4$ & - & - & - & - & - & - & - \\
\hline $\begin{array}{l}\text { Ünsal et al. } \\
(2000)\end{array}$ & $9.5-28.5$ & $30.3-54.3$ & $5.2-12.2$ & - & $0.01-2.8$ & $0.08-25.6$ & $2.9-19.0$ & $0.2-1.9$ & $3.2-16.5$ & - & - \\
\hline $\begin{array}{l}\text { Present } \\
\text { study }\end{array}$ & $8.0-32.0$ & $38.0-43.0$ & $8.8-11.2$ & $6.87-7.43$ & $0.00-0.05$ & $0.012-0.583$ & $0.002-0.115$ & $0.045-0.964$ & $0.288-1.248$ & $4.04-30.93$ & $23.0-184.0$ \\
\hline
\end{tabular}

